\title{
NATURAL RADIATION LEVELS IN POWDERED MILK SAMPLES ${ }^{1}$
}

\author{
F. L. MELQUIADES ${ }^{2, *}$, C. R. APPOLONI ${ }^{3}$
}

\section{SUMMARY}

The control and monitoring of radioactive elements in foodstuffs is fundamental for human health maintenance. This work presents procedures to measure radioactivity levels in powdered milk samples and also a brief discussion of radionuclide transference from the environment to mankind. The measurements were performed utilizing a high-resolution gamma-ray spectrometer using an HPGe detector. The results allowed the quantification of ${ }^{40} \mathrm{~K},{ }^{137} \mathrm{Cs}$ and ${ }^{208} \mathrm{Tl}$ radionuclides. For ${ }^{40} \mathrm{~K}$ the average activity was $482 \pm 37 \mathrm{~Bq} / \mathrm{kg}$ and for ${ }^{137} \mathrm{Cs}$ and ${ }^{208} \mathrm{Tl}$ the lower level of detection was, respectively, $3.7 \pm 1.1$ and $0.5 \pm 0.2(\mathrm{~Bq} / \mathrm{kg})$. The results obtained for the milk samples were compared to data found in the literature and to the limits established by the Brazilian National Commission of Nuclear Energy (CNEN) to assure its safety to human consuption.

Keywords: gamma-ray spectrometry; radioactivity; milk; food.

\section{RESUMO}

NÍVEIS DE RADIOATIVIDADE NATURAL EM AMOSTRAS DE LEITE EM PÓ. A medida de traços radioativos, no ambiente e em elimentos, é de fundamental importância para o monitoramento dos níveis de radiação a que o homem està exposto, direta ou indiretamente. Este trabalho consiste na medida de traços radioativos em leite em pó, através da espectrometria gama de alta resolução. Foi possivel identificar os radionuclídeos ${ }^{40} \mathrm{~K},{ }^{137} \mathrm{Cs}$ e ${ }^{232} \mathrm{Th}$ (obtido do ${ }^{208} \mathrm{Tl}$ ) com as respectivas atividades médias, em $\mathrm{Bq} / \mathrm{Kg}, 482 \pm 37,5,1-11,2$ and 1,6 - 3,7. Os resultados foram comparados com os limites estabelecidos pela Comissão Nacional de Energia Nuclear (CNEN), apresentando níveis normais para os leites analisados, podendo ser consumido sem restrições.

Palavras-chave: radioatividade; espectrometria gama; leite.

\section{1 - INTRODUCTION}

Measurements of radioactivity in environment and in foodstuffs are extremely important for controlling radiation levels to which mankind is direct or indirectly exposed. Besides natural racionuclides, due to several nuclear weapon tests and numerous nuclear reactor accidents, various artificial radioactive elements were introduced in the biosphere. Another important fact is that, importation of contaminated food from any region that suffered a nuclear accident, can be indirectly affect people health around the world [7].

The most important radionuclides associated to internal radiation exposure (due to ingestion of contaminated water and food) and the contamination of the environment, are ${ }^{134} \mathrm{Cs},{ }^{137} \mathrm{Cs},{ }^{137 \mathrm{~m}} \mathrm{Ba},{ }^{131} \mathrm{I},{ }^{89} \mathrm{Sr}$, ${ }^{90} \mathrm{Sr},{ }^{238} \mathrm{Pu},{ }^{239} \mathrm{Pu},{ }^{241} \mathrm{Am},{ }^{242} \mathrm{Cm}$ and tritium. With regard to milk, radionuclides of specific interest are ${ }^{134} \mathrm{Cs},{ }^{137} \mathrm{Cs}$, ${ }^{131} \mathrm{I},{ }^{89} \mathrm{Sr},{ }^{90} \mathrm{Sr}[3]$. As they decay at different rates, the doses from these elements and other radionuclides, are delivered in different manners.

Nowadays, elements with short half-live as, for instance, ${ }^{131}$ I (half-live $8,021 \mathrm{~d}$ ), ${ }^{89} \mathrm{Sr}$ (half-live 50,5 d) and ${ }^{134} \mathrm{Cs}$ (half-live $754,2 \mathrm{~d}$ ), almost inexist in

\footnotetext{
Recebido para publicação em 25/05/2002. Aceito para publicação em 04/10/2004 (000855).

2. Dep. of Chemistry and Physics - Universidade Estadual do Centro Oeste, Caixa Postal 3010, CEP: 85015430, Guarapuava-PR, Brazil. E-mail: fmelquiades@unicentro.br

3. Dep. of Chemistry and Physics - Universidade Estadual de Londrina, CCE, Caixa Postal 6001, CEP: 86051-990, Londrina-PR, Brazil

* A quem a correspondência deve ser enviada.
}

environment and food, except in regions where there were some kind of nuclear accident. ${ }^{137} \mathrm{Cs}$ and ${ }^{90} \mathrm{Sr}$ both with long half live (something of about 30 years) have delivered most of their doses by the end of the last century.

Literature about ${ }^{137} \mathrm{Cs}$ and other radionuclides found in foodstuffs of countries at the North hemisphere is very abundant. In the other hand, in countries in the South hemisphere, especially in Latin America, there are few studies about this matter. In Brazil, most of the quantitative data about natural radioactivity was obtained in Rio de Janeiro State. In this region several products like milk, meat, leafy vegetgables, fruit, root, bean, rice and derived products (sugar, coffee, flour, etc) $[5,10]$ were analyzed. A detailed research about radiation levels in milk can be found in SANTOS FILHO \& KRETER [11] and DE NADAI et al. [2].

Investigation of ${ }^{137} \mathrm{Cs},{ }^{90} \mathrm{Sr}$ and ${ }^{40} \mathrm{~K}$ levels in milk and its products are monitored in a numerous regions of the world $[4,6,12,17]$.

Annual radiation doses exibit peaks in 1958-1960 and 1963-1964 (years where nuclear weapon tests had their apex). Figure 1, shows the activity of ${ }^{137} \mathrm{Cs}$ and ${ }^{90} \mathrm{Sr}$ in foodstuffs at that time. Only $12 \%$ of these doses had been delivered by 1980, the remainder doses will be delivered over millions of years [15].

Radionuclides sources on human diet are come mainly from milk, meat and other products more frequently consumed. Powdered milk, is an important ingredient used to make cookies, ice cream, yogurt, chocolate, powdered chocolate and many others human aliments. Also, it is the main source of nutrients for newborn childer and its more pratical to be stored. 
Although, higher concentrations of radionuclides are found in powered milk as compared with in natura milk (around 8.5 liters of in natura milk are necessary to produce $1.0 \mathrm{~kg}$ of powdered milk). So its essential to check if its radiation levels do not signify any risk to human health.
STRONTIUM-9O IN DIET

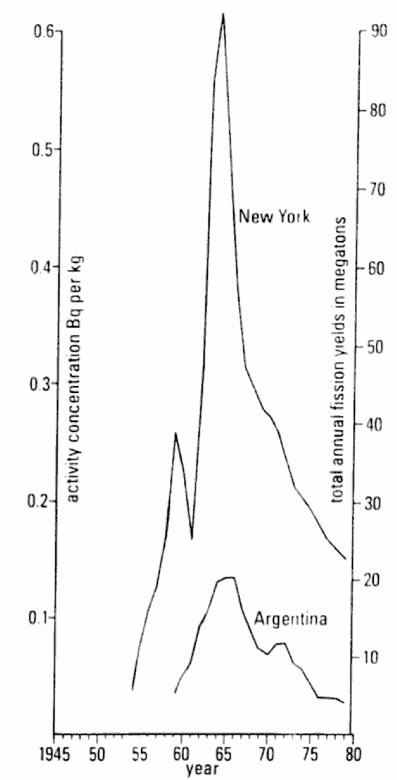

CAESIUM-137 IN DIET

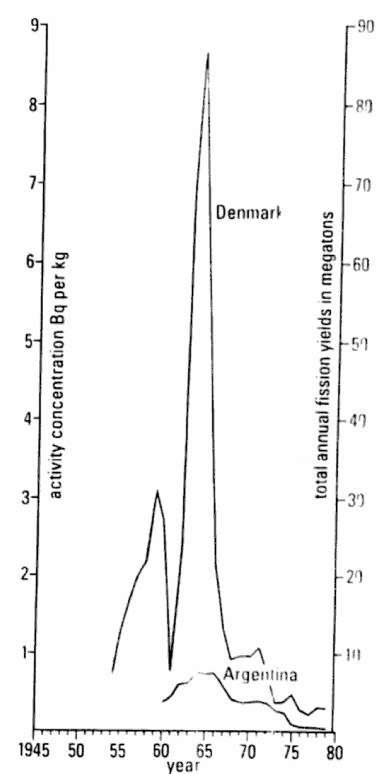

FIGURE 1. Levels of Strontium-90 and Caesium-137 in the total diet, compared with the annual yield from atmospheric nuclear tests. Note the much higher exposures in the northern hemisphere (New York and Denmark) than in the southern hemisphere (Argentina) [16].

Brazilian National Commission of Nuclear Energy [14] established radioactive limits for powdered milk and other products. The maximum value for the sum of ${ }^{134} \mathrm{Cs}$ and ${ }^{137} \mathrm{Cs}$ in powdered milk is $370 \mathrm{~Bq} / \mathrm{kg}$ and $600 \mathrm{~Bq} / \mathrm{kg}$ for other kinds of food.

The objective of this work is to identify and quantify radionuclides in powdered milk samples produced in Londrina, Paraná, a region located in South part of Brazil. Also is discussed, briefly, its impact in the transference of radionuclides from the environment to the man.

\section{1 - ORIGIN OF THE RADIONUCLIDES IN FOODSTUFFS}

Main source of radionuclides in foodstuffs comes from artificial radioactive elements, due to the "fallout", i.e., the precipitation or deposition of radioactive elements on terrestrial surface. Superficial tests of nuclear bombs and nuclear reactors accidents caused the appearance of several artificial radioactive elements. Leak of nuclear reactors originated local fallouts, that mainly contaminates regions around the nuclear factory. Otherwise, superficial tests using nuclear bombs could originate local, regional or global fallout, depending on the magnitude of the explosion, and the height of the radioactive cloud.

In a global scale, radionuclide elements coming form the fallout incorporates in biosphere. These elements present in atmosphere contaminate plants, soil and water and by different ways contaminate the environment. The radioactive elements transport in environment involves transference among three primary components: vegetation, soil and water [09]. Figure 2 shows the cycle of incorporation of ${ }^{137} \mathrm{Cs}$ in the environment. This model describes several environmental transference process and biocontamination factors. The example shows radionuclides of ${ }^{137} \mathrm{Cs}$, nevertheless many other radioactive element have the same behavior.

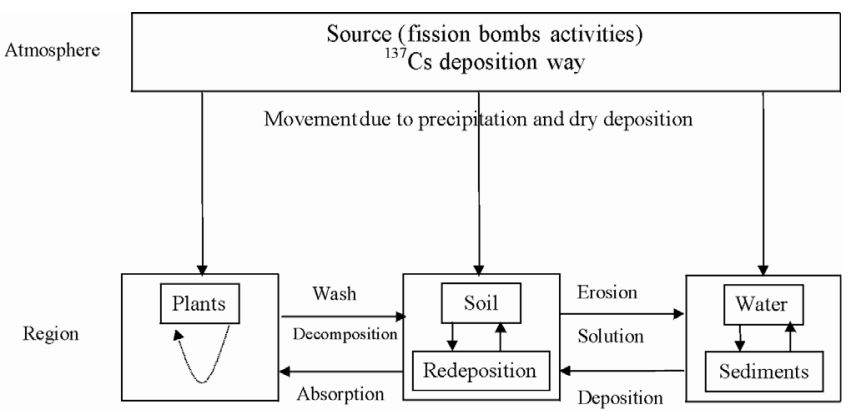

FIGURE 2. ${ }^{137} \mathrm{Cs}$ incorporation cycle diagram in the nature [09].

Figure 3, describes the cycle of radionuclides incorporation in the soil until its finally absorption for the man. Greatest contamination are achieved when cows graze during fallout periods ingesting pasture grass and soil [13]. Even if they are kept indoors, contamination of milk may occur by inhalation of radionuclides or ingesting them in drinking water and contaminated feed. Milk from goat and sheep, should be checked periodically over a longer period because their grazing habits [15].

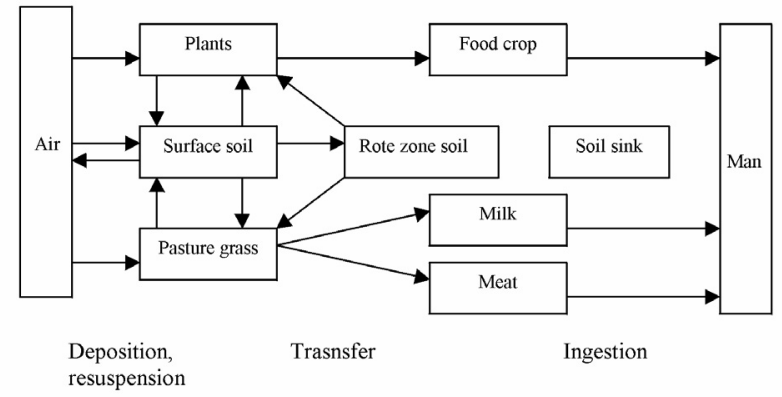

FIGURE 3. A typical set of pathways through the environment from a radiation source exposed to the air [15].

\section{3 - MATERIALS AND METHODS}

Two different brands of cow powdered milk, produced in the region of Londrina, were analyzed by highresolution gamma-ray spectrometry. A coaxial HPGe 
(High Purity Ge crystal) detector with $10 \%$ relative efficiency, coupled to a standard nuclear electronics associated to an $8 \mathrm{~K}$ multichannel card was used. The total energy resolution measured was $1.95 \mathrm{keV}$ for the $1408.12 \mathrm{keV}$ line and $1.39 \mathrm{keV}$ for the $344.28 \mathrm{keV}$ line, both emitted from ${ }^{152} \mathrm{Eu}$ radionuclides.

A number of tests were performed to define system shield, sample geometry, number of samples (by statistical inference) and self absorption correction [7, 8].

The two milk brands analyzed named here as, Milk 1 and Milk 2, were put in 2.1 liters Marinelli beakers, and their net mass varied from 1130 to $1230 \mathrm{~g}$. Table 1 presents the main samples characteristics. Three measurements of 172800 s were performed to record the sample and background radioactivity levels. Also, to monitor the system calibration during the experiments, it was measured the radiation emited from an ${ }^{152} \mathrm{Eu}$ source for $24 \mathrm{~h}$ period.

TABLE 1. Milk samples characteristics.

\begin{tabular}{ccccc}
\hline Milk & Density $\left(\mathrm{g} / \mathrm{cm}^{3}\right)$ & Moisture & $\begin{array}{c}\text { Measured } \\
\text { Moisture* }\end{array}$ & $\begin{array}{c}\text { Fabrication } \\
\text { Date }\end{array}$ \\
\cline { 1 - 5 } Milk 1 & $0.554 \pm 0.008^{\#}$ & $2.8-3 \%$ & $4.7 \pm 0.3^{\#} \%$ & $30 / 08 / 1998$ \\
Milk 2 & $0.542 \pm 0.007^{\#}$ & $3 \%$ & $5.2 \pm 0.2^{\#} \%$ & $14 / 08 / 1998$ \\
\hline
\end{tabular}

* Average value from the six prepared samples

Standard Deviation

Supplied by the manufactor

The radionuclides activity of the samples was calculated according to the expression [3]:

$A=\frac{\alpha N_{L} f}{m t}$

where $A$ is radionuclide activity of interest, $t$ is the count time (172800s), $m$ is the net sample mass, $N_{L}$ is the net count under the analyzed radionuclide peak, $f$ is the self absorption factor and $a$ a calibration factor, calculated using certified samples, IAEA 375 and IAEA 326. The $a$ factor includes detector efficiency and branching ratio factor of the gamma line.

\section{4 - RESULTS \& DISCUSSION}

In the obtained milk samples spectra it was possible to identify clearly the $1460.8 \mathrm{keV}$ line $\left({ }^{40} \mathrm{~K}\right)$, and also, with some difficulty due to the very low activity, the $661.22 \mathrm{keV}\left({ }^{137} \mathrm{Cs}\right)$ and $2614.4 \mathrm{keV}\left({ }^{208} \mathrm{Tl}\right)$ lines. The lower level of detection for these three lines were, respectively, $2.3,3.7$ and $0.5 \mathrm{~Bq} / \mathrm{kg}$, obtained according to IAEA norms [3]. The results for Milk 1 and Milk 2 are summarized in Table 2. A spectrum of Milk 1 (very similar to Milk 2) is shown in Figure 4. As ${ }^{137} \mathrm{Cs}$ activity was low and the background was relatively high the peak due to ${ }^{137} \mathrm{Cs}$ was not visible.

In Table 3, the obtained results are compared with some data from imported milks encountered in Brazil [2], and with some measurements performed in Venezuela [4]. All results presented in this table were obtained by the same technique and the activity values were found in the range measured for these radionuclides reported to other milk brands.

TABLE 2. Statistical activity results for Milk 1 and Milk 2 samples (in dry mass).

\begin{tabular}{|c|c|c|c|}
\hline \multicolumn{4}{|c|}{ Milk 1} \\
\hline Nuclide & Activity & $\begin{array}{l}\text { Activity } \\
{ }^{137} \mathrm{Cs}\end{array}$ & $\begin{array}{l}\text { Activity* } \\
{ }^{232} \mathrm{Th}\end{array}$ \\
\hline $\mathrm{N}$ & 18 & 18 & 18 \\
\hline Mean $(\mathrm{Bq} / \mathrm{kg})$ & 489 & $<3.7$ & $<0.5$ \\
\hline $\mathrm{S}_{\mathrm{r}}(\mathrm{Bq} / \mathrm{kg})$ & 13 & 1.1 & 0.2 \\
\hline $\mathrm{RSD}_{\mathrm{r}}$ & $2.65 \%$ & $30.4 \%$ & $35.4 \%$ \\
\hline$r(B q / k g)$ & 36.4 & 3.1 & 0.5 \\
\hline \multicolumn{4}{|c|}{ Milk 2} \\
\hline Nuclide & Activity & $\begin{array}{l}\text { Activity } \\
{ }^{137} \mathrm{Cs}\end{array}$ & $\begin{array}{l}\text { Activity* } \\
{ }^{232} \mathrm{Th}\end{array}$ \\
\hline $\mathrm{N}$ & 18 & 18 & 18 \\
\hline Mean $(\mathrm{Bq} / \mathrm{kg})$ & 475 & $<3.4$ & $<0.3$ \\
\hline $\mathrm{S}_{\mathrm{r}}(\mathrm{Bq} / \mathrm{kg})$ & 12 & 0.7 & 0.1 \\
\hline $\mathrm{RSD}_{\mathrm{r}}$ & $2.53 \%$ & $19.7 \%$ & $38.2 \%$ \\
\hline$r(B g / k g)$ & 33.6 & 1.9 & 0.4 \\
\hline
\end{tabular}

$\mathrm{N}$ : number of determinations; $\mathrm{S}_{\mathrm{r}}$ : standard deviation; $\mathrm{RSD}_{\mathrm{r}}$ : relative standard deviation

of repeatability; $\mathrm{r}$ : repeatability $\mathrm{r}=2.8 \mathrm{~S}_{\mathrm{r}}$.

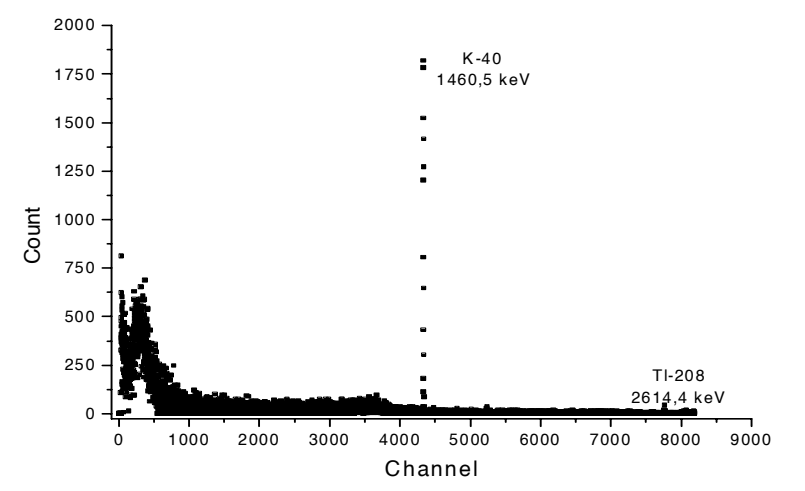

FIGURE 4. Measured spectrum of Milk 1 (counting time 172,800 s).

TABLE 3. Activities results of ${ }^{40} \mathrm{~K}$ and ${ }^{137} \mathrm{Cs}$ obtained by gamma-ray spectrometry in powdered milk samples, compared with data from the literature.

\begin{tabular}{|c|c|c|}
\hline Milk trademark & Activity of ${ }^{40} \mathrm{~K}(\mathrm{Bg} / \mathrm{kg})$ & Activity of ${ }^{137} \mathrm{Cs}(\mathrm{Bg} / \mathrm{kg})$ \\
\hline Milk 1 & $475 \pm 12$ & $<3.7$ \\
\hline Milk 2 & $489 \pm 13$ & $<3.4$ \\
\hline Itambé $e^{(a)}$ & 492.89 & \\
\hline Duleit $^{(a)}$ & 490.52 & \\
\hline Glória $^{(a)}$ & 514.28 & \\
\hline $\mathrm{Klim}^{(\mathrm{a})}$ & 362.16 & \\
\hline La Campiña ${ }^{(b)}$ & $329 \pm 20$ & $1.43 \pm 0.4$ \\
\hline La Pradera $^{(b)}$ & $401 \pm 40$ & $1.66 \pm 0.4$ \\
\hline Indosa ${ }^{(b)}$ & $440 \pm 30$ & $1.33 \pm 0.4$ \\
\hline Popular $1^{(b)}$ & $423 \pm 40$ & $0.98 \pm 0.3$ \\
\hline Popular $2^{(\mathbf{b})}$ & $398 \pm 30$ & $1.38 \pm 0.3$ \\
\hline Camprolac $^{(b)}$ & $421 \pm 20$ & $1.83 \pm 0.4$ \\
\hline Rika $^{(b)}$ & $400 \pm 20$ & $2.21 \pm 0.5$ \\
\hline
\end{tabular}

(a) $[2],{ }^{(b)}[4]$

Table 4 shows the results here obtained to the ${ }^{137} \mathrm{Cs}$ activity found in in natura milk samples, in comparison 
to that ones found in the reference [17]. For the comparison, the results presented in Table 2 were converted to liquid milk, employing the "reduction factor" of 8.5 , supplied by the producer (8.5 liters of natural milk to produce one kilogram of powdered milk). For ${ }^{40} \mathrm{~K}$ activity values are in good agreement with the data presented in the literature.

TABLE 4. ${ }^{40} \mathrm{~K},{ }^{137} \mathrm{Cs}$ and ${ }^{232} \mathrm{Th}$ activities in milk samples.

\begin{tabular}{cccc}
\hline & ${ }^{40} \mathrm{~K}(\mathrm{~Bq} / \mathrm{L})$ & ${ }^{13 /} \mathrm{Cs}(\mathrm{Bq} / \mathrm{L})$ & ${ }^{232} \mathrm{Th}(\mathrm{Bq} / \mathrm{L})$ \\
\hline Milk 1 & $55 \pm 2$ & $<0.43$ & $<0.06$ \\
Milk 2 & $53 \pm 2$ & $<0.40$ & $<0.04$ \\
Hong Kong Milk [17] & $48 \pm 1$ & $0.01-0.08$ & $<0.1$ \\
\hline
\end{tabular}

\section{5 - CONCLUSIONS}

The radionuclides ${ }^{40} \mathrm{~K},{ }^{137} \mathrm{Cs}$ and ${ }^{208} \mathrm{Tl}$ could be identified in Milk 1 and Milk 2 sample spectra. ${ }^{232}$ Th activity was calculated from ${ }^{208} \mathrm{Tl}$ data, assuming the secular equilibrium between this samples. Statistical data analysis confirmed the measurements quality and showed the equivalence among repetitions.

The values of activity found to ${ }^{137} \mathrm{Cs}$ are lower than $10 \%$ of maximum level recommended by Brazilian National Commission of Nuclear Energy (CNEN) [1]. At the opposite, the ${ }^{40} \mathrm{~K}$ activity was bigger. As the potassium is rough uniformly distributed in the body, folows intaked in foods, and its concentration in the body is under homeostatic control [14], it is less dangerous for human health than ${ }^{137} \mathrm{Cs}$.

In general terms, it can be concluded that the implemented technique presented good results when compared with other literature data. Also it can be concluded that milks here analysed are safe for human consuption because their radioactivity levels are lower than the maximum levels permitted by CNEN [1].

\section{6 - REFERENCES}

[1] CNEN-NE-3.01. 1988. Basic appointments of radioprotection. Rio de Janeiro.

[2] DE NADAI, E.A.; FERRAZ, E.S.B.; PESSENDA, L.C.R.; NASCIMENTO FILHO, V.F. Anual abstracts of II Congresso Geral de Energia Nuclear, Rio de Janeiro, 1988.

[3] IAEA 295 - International Atomic Energy Agency. 1989. Measurements of radionuclides in food and the environment: a Guidebook. Viena.

[4] LABRECgUe, J.J.; ROSAlleS, P.A.; CARIAS, O. Nu- clear Instruments and Methods in Physics Research, v. A312, p. 217-222, 1992.

[5] MALANCA, A.; SOGNI, R.; MACEDO, H.R. Radium, potassium, and caesium in foodstuffs from a Brazilian state. Journal of Environmental Science and Health Part A-Toxic/Hazardous Substances \& Environmental Engineering, v. 34, n. 2, p. 423-433, 1999.

[6] MARMUlEVA, N.I.; BARINOV, E.Y.; PETUKHOV, V.L. Radionuclides accumulation in milk and its products. Journal de Physique IV, v. 107, p. 827-829, Part 2, 2003.

[7] MELgUiAdES, F.L.; APPOLONI, C.R. 40K, 137Cs and $232 \mathrm{Th}$ activities in brazilian milk samples measured by gamma ray spectrometry. Indian Journal of Pure and Applied Physics. v. 40, p. 5-11, 2002.

[8] MELQUiAdES, F.L.; APPOLONI, C.R.. Self Absorption correction on gamma spectrometry of powdered milk samples using Marinelli beaker. Appl Radiat Isot. v. 55, n. 5, p. 697-700, 2001.

[9] RITCHIE, J.C.; MCHENRY, J.R. Application of Radioactive Fallout Cesium-137 for Measuring Soil Erosion and Sediment Accumulation Rates and Patterns: A Review. Journal of Environmental Quality, v. 19, p. 215-233, 1990.

[10] SANTOS, E.E.; LAURIA, D.C.; AMARAL, E.C.S.; ROCHEDO, E.R. Daily ingestion of Th-232, U-238, Ra226, Ra-228 and Pb-210 in vegetables by inhabitants of Rio de Janeiro City. Journal of Environmental Radioactivity, v. 62, n. 1, p. 75-86, 2002.

[11] SANTOS FILHO, A.M.S.; KRETER, R.N. Ocorrência de ${ }^{137} \mathrm{Cs}$ devido a Fall Out em amostras de leite na região circunvizinha ao CIR - Resende - RJ. XI ENFIR/IV ENAN Joint Nuclear Conference, Poços de Caldas, MG - Br; 1997.

[12] SHUKLA, V.K.; MENON, M.R.; RAMACHANDRAN, T.V.; SATHE, A.P.; HINGORANI, S.B. Natural and fallout radioactivity in milk and diet samples in Bombay and population dose-rate estimates. Journal of Environmental Radioactivity, v. 25, n. 3, p. 229-237, 1994.

[13] TSUKADA, H.; HISAMATSU, S.; INABA, J. Transfer of Cs-137 and stable Cs in soil-grass-milk pathway in Aomori, Japan, Journal of Radioanalytical and Nuclear Chemistry, v. 255, n. 3, p. 455-458, 2003.

[14] UNCEAR, Sources and Effects of Ionizing Radiation, Report Vol I, Anex B, p. 94, 2000.

[15] UNEP - United Nations Environment Programme. Radiation doses, effects, risks. $2^{\text {nd }}$ ed. Cambridge, Massachusetts. 89p, 1991.

[16] UNEP - United Nations Environment Programme. Radiation doses, effects, risks. $1^{\text {st }}$ edition. Cambridge, Massachusetts. 64p, 1985.

[17] YU, K.N.; MAO, S.Y. Application of High Resolution Gamma Ray Spectrometry Measuring Radioactivities in Drinks in Hong Kong. Applied Radiation Istotopes. v. 45, n. 10, p. 1031-1034, 1994. 